\title{
The Alien Test: \\ An Outside View of Human Responses to Mental Distress
}

\author{
Mary O'Hagan \\ Member of the New Zealand Order of Merit; former New Zealand Mental Health \\ Commissioner; Director of PeerZone, peer-led workshops in mental health and addiction, and \\ Swell, the online recovery toolkit.
}

\begin{abstract}
This commentary imagines what responses to mental distress on Planet Earth might look like to a rational, humane alien from a planet where responses to people with mental distress are compassionate and just. The alien visits Canada and New Zealand and concludes that discrimination skews social and service responses and that the narrow, deficits approach to services does not improve outcomes. Despite this, the alien perceives little sense of urgency for change. The alien then describes the recovery-oriented responses on their own planet and makes recommendations for system change on Planet Earth. The alien points out that deep change in a system with finite resources will require removing the "control" elements of services, closing hospitals, and reducing the dominance of biological psychiatry. The alien emphasizes that it is not sufficient just to build the leadership of people with mental distress, provide a broader range of services for diverse cultures and communities, and promote social inclusion if the failed elements of the old system remain.
\end{abstract}

Keywords: recovery-based systems, system transformation, outcomes, mental health policy

\section{RÉSUMÉ}

Imaginons qu'un extraterrestre, à la fois lucide et sensible, arrive sur Terre venant d'une planète dont les habitantes et habitants qui souffrent de détresse psychologique sont traités avec empathie et équité. Dans ce commentaire, je décris les réactions que cet extraterrestre pourrait avoir devant la façon dont les Terriennes et Terriens qui souffrent de détresse psychologique sont traités. Après s'être rendu au Canada et en Nouvelle-Zélande pour observer la situation, l'extraterrestre conclut que, sur le plan social et au niveau des services offerts, le traitement de la détresse psychologique est empreint de discrimination, et que les approches étriquées et axées sur les déficits sur lesquelles se fondent les services n'aident pas les gens à améliorer leur condition. L'extraterrestre note également que, malgré cela, peu de gens semblent conscients de l'urgence de changer la situation. L'extraterrestre décrit alors le système de soins axés sur le rétablissement mis en place sur sa planète, et fait quelques recommandations aux Terriens et Terriennes. L'extraterrestre souligne, entre autres, qu'un profond changement dans un système de santé dont les ressources sont limitées impliquera : l'abandon des aspects des soins qui visent à contrôler les personnes vivant avec un problème de

Mary O’Hagan, consultant, writer, speaker, PeerZone developer. PO Box 6627, Marion Square, Wellington 6011, New Zealand. Email: mary@ohaganmccookweir.com. Tel: +64 4 3854277. Websites: www.maryohagan.com; www.peerzone.info; www.madness mademe.com 
santé mentale; le remplacement des services offerts en milieu hospitalier par des soins dans la communauté; et la fin de la toute-puissance de la psychiatrie biologique. L'extraterrestre insiste aussi sur le fait que, même si l'on développe le leadership des personnes souffrant de détresse psychologique, que l'on offre plus de services adaptés à différentes cultures et communautés et que l'on favorise l'inclusion sociale, cela ne sera pas suffisant si les éléments défectueux du système actuel restent en place.

Mots clés : soins axés sur le rétablissement, transformation du système, résultats, politiques en matière de santé mentale

Imagine what human responses to people with major mental distress would look like to a rational, empathic alien with a commitment to social justice. Let's say this alien comes from Planet Aequalis and visits Planet Earth to compare human responses to Planet Aequalis's compassionate, just, and rational responses to mental distress. The executive summary of the alien's report might read something like this:

\section{BACKGROUND}

I beamed into two countries on Planet Earth - Canada and New Zealand - to find out how they respond to people with mental distress and to make recommendations for both countries based on our practices on Planet Aequalis. I read documents, and I talked to people with mental distress, and to the leaders in their mental health systems, researchers, and advocates. I was bewildered by what I found, particularly because the two countries I visited are wealthy democracies that value freedom and equal opportunities.

My assessment of human responses to mental distress needs to be understood in the context of human strengths and limitations as a species. Humans are an intelligent species with huge capacity for innovation but they possess a number of peculiarities. They are hierarchical and competitive, and they develop elaborate systems to rank people. As a consequence of this and other environmental uncertainties, humans experience fear and related emotions, which can generate much compassion but also acts of cruelty. Their compassion is rarely unconditional, and they often justify their cruelty on the basis of imminent threat or even benevolence.

\section{RESPONSES TO MENTAL DISTRESS ON PLANET EARTH}

Humans can experience occasional extreme states of mind characterized by fear, despair, confusion, and sometimes elation. A majority of humans experience some form of mental distress during their lifetime and often recover quickly, but a small percentage may be more severely affected for a longer period. My research sources told me severely affected people in Canada and New Zealand tend to have trauma histories or come from disadvantaged cultural and socioeconomic groups. They live up to 25 years less than average; around $80 \%$ of them have no productive role; a higher percentage than average are single and childless; many homeless people and prisoners have major mental distress; and they are around 20 times more likely than other citizens to die by suicide. These are tragic determinants and outcomes that we have averted, to a large degree, on Planet Aequalis.

Canada and New Zealand both have mental health systems where the vast majority of funding goes to hospitals, clinical services, and medications. The rest goes to community-based support services that provide 
housing and assistance with day-to-day living and social integration. Mental health systems have two purposes that are often contradictory - to help people recover and to control them. There is huge community and political pressure for the services to exercise their control function-mostly within the clinical service setting using legislation to compulsorily detain and treat people.

I talked to people in both counties who use mental health services. They told me about their profound crises of being and how they often feel shunned by society and punished by service systems for their suffering. I then asked what helped them to recover and experience positive life outcomes. They said they need others to believe in them and to be treated as valued members of their families and communities. They want to feel in control of their destiny and to work, love, and play like other humans.

I asked these people if hospitals and medications were helpful. They were ambivalent. Although clinical approaches can quell their crises of being, they sometimes feel harmed by these services, especially if they are forced to use them. They said they want more practical support in housing, education, and employment, and in day-to-day living. They talked about the value of peer support and services that restore their personal power but said these services are few.

I then asked several mental health leaders why so much money is spent on clinical services that focus primarily on controlling people, especially as they tend to be inhumane and ineffective. They told me the community expects them to force people to go to hospital and take treatment. If they fail to avert individual tragedies they must publicly explain themselves and suffer reputational damage. Most agreed these clinical systems can be harmful to people and that the poor life outcomes are preventable. It appears, however, that their failure to avert personal harm or poor outcomes has no adverse impact on their reputations in the way that failure to control people does.

I then talked to some people who study human societies to get their explanation for this irrational and unfair situation. The problem starts with stigma and discrimination, they said. People with mental distress have been treated as less than human in many societies for many centuries because others fear them and don't understand their behaviour. As a result, mental health services are poorly funded and most of the resources go to expensive institutional responses dedicated to controlling people.

In countries like Canada and New Zealand, large institutional systems have been developed over the last 200 years to deal with human problems that communities and families once dealt with; these systems are granted great powers to make judgements about people's experiences and impose remedies. The professionals who run these systems are the new priesthood, and the community defers to their expertise. Psychiatrists often believe mental distress is a brain disease, but some informants said there no empirical evidence for this. Psychiatric drug treatments are poorly targeted, have a marked placebo effect, and can endanger people's physical health. There is substantial evidence that these drugs do not improve outcomes at the population level.

Some of my informants said it is difficult to change systems because the leaders and commercial interests such as drug companies derive status or wealth from them. Others explained that although a lot of power is wielded in the mental health system individuals feel powerless to change what goes on. The leaders tend to blame other parts of the system and have difficulty collaborating for the benefit of people with mental distress. Humans don't always cope effectively with too much complexity in their systems. For instance, they are facing a crisis in global warming largely due to human pollution but their governments cannot agree on a way to reduce greenhouse gasses. 
My overall impression of responses to people with mental distress in the countries I visited are:

- Stigma and discrimination skew the way services respond to people with mental distress toward control, and limit the opportunities of people with mental distress to recover and participate in society.

- Mental health services have been dominated by Eurocentric professionals with a narrow, deficitsbased approach focused on hospitals, diagnosis, and medication, an approach that has failed to improve outcomes and may have even worsened them.

- There is little sense of urgency to change social and service responses because of vested interests, tolerance for personal harm and poor life outcomes, and cumbersome systems that reward the status quo and suppress innovation.

\section{RESPONSES TO MENTAL DISTRESS ON PLANET AEQUALIS}

Despite this absurd and tragic situation, many working in services I visited try hard to support recovery for people with mental distress. Canada, New Zealand, and other high-income countries have officially adopted a recovery approach in their policy, but it is poorly defined and implemented. Advocates agreed the recovery approach is consistent with societal and service responses on Planet Aequalis as outlined below and could be emulated on Planet Earth.

There is very little stigma and discrimination on Planet Aequalis. Mental distress is viewed primarily through the eyes of the inhabitants who experience it - as a legitimate though challenging experience that value and meaning can be derived from - with multiple determinants and consequences that require multiple responses.

The purpose of mental health services on Planet Aequalis is for inhabitants to lead their own recovery in a milieu that is underpinned by hope, self-determination, a broad choice of services, and social inclusion. Inhabitants with mental distress are encouraged to be active agents in their own recovery. Those working in services walk alongside people and have hope for them; many have openly acknowledged lived experience and come from diverse cultures and backgrounds. Families are educated to support recovery. Communities, opinion leaders, and politicians generally speak favourably of inhabitants with mental distress and expect them to be treated fairly.

The culture of services in Planet Aequalis is egalitarian and community-facing. Services are situated in "natural" community settings. Those in crisis are cared for in community houses where their fellow inhabitants, rather than locks and keys, keep them safe. The services value subjectivity and the language of experience. Inhabitants who use the services have the skills and resources to monitor them and demand improvements. There is no special mental health legislation that takes away an inhabitant's right to consent but generic, supported-decision-making legislation applied on an equal basis to all inhabitants.

There is a much broader range of core services on Planet Aequalis than Planet Earth. Most of these responses are not medical. Service navigation, peer support, recovery education, advocacy, personal assistance in crisis, and personal assistance in day-to-day living, as well as talking therapies and culturally based services, are as available as drug therapy to all inhabitants who experience mental distress on Planet Aequalis. 
The workforces and agencies that deliver services on Planet Aequalis have found many successful ways to work together: for example, through joint planning and pooled funding; moving workforces between teams, services, and sectors; information sharing; and shared use of communications technologies for online service provision. Different sectors such as social services, employment, and justice view it as part of their core business to serve the needs of people with mental distress in collaboration with other sectors.

Planet Aequalis has an overarching systemic framework to support its equitable treatment of people with mental distress. Governments develop social and economic policy to optimize well-being and to minimize social determinants of mental distress such as childhood neglect, trauma, and inequality. Legislation that affects people with mental distress cannot be passed if it does not meet stringent equality criteria. Policy and funding span across sectors and push services into the future rather than reinforcing the status quo. The development of research and the workforce gives equal weight to knowledge and approaches based on lived experience and cultural diversity as it does to professional perspectives. At the local and national levels Planet Aequalis has established well-resourced service-monitoring networks led by inhabitants with mental distress, their families, and their communities.

\section{RECOMMENDATIONS FOR IMPROVING RESPONSES ON PLANET EARTH}

Planet Aequalis's treatment of people with mental distress exemplifies how a recovery approach can be put into practice. I recommend seven key pathways to improving responses to people with mental distress on Planet Earth:

1. Build the leadership of people with mental distress in their own recovery and in the development, delivery, management, governance, and evaluation of services.

2. Remove the "control" purpose of services by repealing mental health legislation and ensuring that any treatment without consent is decided on an equal basis with other citizens.

3. Replace all or most hospital services with community- and home-based services.

4. Reduce the dominance of biological treatments and develop integrated core services that restore personal power, cultural connection, equal participation, and economic security.

5. Acknowledge the harm done by psychiatry, heal the trauma in individuals and in the system, and move workforces toward recovery-based values and competencies.

6. Run ongoing recovery- and human rights-based social inclusion programs led by people with mental distress.

7. Develop whole-of-government approaches to increasing population well-being and reducing the social and economic determinants of mental distress.

\section{FIT WITH MENTAL HEALTH POLICIES}

I analyzed the above recommendations to see if they are reflected in the national mental health policies in Canada and New Zealand (see Appendix 1 for a comparison of these policies). Current policies in both countries go some way toward echoing these recommendations; for instance, both policy documents state 
their intentions to build the leadership of people with mental distress, provide a broader range of services for diverse cultures and communities, and promote social inclusion. These can be seen as "additive" policies. However, an ineffective system with finite resources needs to give as much consideration to "subtractive" policies to remove the services and system drivers that conflict with recovery and to divert those resources to new recovery-based approaches. There is virtually no subtractive policy in the current mental health policies of either Canada or New Zealand that would dismantle the status quo through removing the "control" elements of services - closing hospitals or reducing the dominance of biological psychiatry. As a consequence their policies are overcrowded wish lists; they clip recovery approaches onto a control structure that negates recovery values and continues to soak up most of the resources. Furthermore, the policies have been developed by agencies that do not have the power to implement them or make decisions on the allocation of funding.

\section{CONCLUSION}

The responses to people with major mental distress on Planet Earth within their service systems and in the wider society are often irrational and inhumane. At best these responses are partially effective and at worst they are deeply harmful. A similar situation on Planet Aequalis would be regarded as scandalous and rectified urgently. The inhabitants of Planet Earth tend to be aware of the problems in their midst, but their ability to create change can be compromised by denial, discrimination, self-interest, and an inability to deal with complex systems.

On the other hand, humans have been able to make profound improvements to the way they respond to some groups. One recent example in the countries I visited was the increased acceptance and ranking of people who have sexual relationships with people of the same gender (known as gay people). A generation ago their activities were illegal in Canada and New Zealand. Now they can get married. There is still hope that changes as profound as this may greatly benefit the lives of people with major mental distress. This will require a positive shift in attitudes toward people with major mental distress as well as deep and disruptive transformation of the systems that serve them. The responses to people with mental distress on Planet Aequalis can provide sound guidance in making this transformation. 


\section{APPENDIX 1 Mental Health Policies in Canada and New Zealand}

Canada has a federal political system that devolves most of the funding and delivery of health services to the provincial and territorial governments. Its first national mental health policy was developed by the independent Mental Health Commission of Canada (2012) established by the federal government. The policy covers mental illness prevention, mental health promotion, and mental health services.

New Zealand has a centralized political system. The Ministry of Health advises the Minister of Health and develops policy. Responsibility for funding and delivery of health services is devolved to District Health Boards. New Zealand's current mental health plan (New Zealand Ministry of Health, 2012) is focused on mental health services. There is no current overarching strategy for promotion and prevention, but a suicide action plan and an anti-discrimination program plan are referred to in the mental health service plan.

A summarized comparison of the two policies is set out in Table 1.

Table 1

Mental Health Policies, Canada and New Zealand

\begin{tabular}{|c|c|c|}
\hline & $\begin{array}{l}\text { Canada: } \\
\text { Changing Directions, Changing Lives }\end{array}$ & $\begin{array}{l}\text { New Zealand: } \\
\text { Rising to the Challenge }\end{array}$ \\
\hline Promotion & $\begin{array}{l}\text { Promote mental health across the lifespan-in } \\
\text { communities, schools, and workplaces. }\end{array}$ & Develop mental health literacy. \\
\hline Prevention & Prevent mental illness and suicide. & Develop suicide-prevention plan. \\
\hline Recovery & $\begin{array}{l}\text { Foster recovery and well-being in people with mental } \\
\text { health problems. }\end{array}$ & $\begin{array}{l}\text { Cement resiliency and recovery for low-prevalence } \\
\text { conditions. }\end{array}$ \\
\hline Rights & $\begin{array}{l}\text { Uphold the rights of people with mental health problems: } \\
\text { Develop alternatives to seclusion and restraint. }\end{array}$ & Reduce and eliminate seclusion and restraint. \\
\hline $\begin{array}{l}\text { Stigma and } \\
\text { discrimination }\end{array}$ & Eliminate attitudinal, behavioural, and structural barriers. & Enhance social inclusion opportunities. \\
\hline Service range & $\begin{array}{l}\text { Coordination, primary health, specialist clinical services, } \\
\text { peer support, housing, employment, education, and } \\
\text { families. }\end{array}$ & $\begin{array}{l}\text { Primary/secondary service integration, self-management } \\
\text { education, peer support, employment, acute inpatient } \\
\text { alternatives, talking therapies. }\end{array}$ \\
\hline $\begin{array}{l}\text { Social } \\
\text { determinants }\end{array}$ & $\begin{array}{l}\text { Reduce disparities in risk factors for "at risk" groups: } \\
\text { ethnocultural, socioeconomic, gender/sexual orientation. }\end{array}$ & $\begin{array}{l}\text { Work to identify and address disparities for Maori and } \\
\text { other groups with disparities in health outcomes. }\end{array}$ \\
\hline Access & $\begin{array}{l}\text { Reduce disparities in access to mental health services for } \\
\text { "at risk" groups: ethnocultural, socioeconomic, gender/ } \\
\text { sexual orientation. }\end{array}$ & $\begin{array}{l}\text { Increase access for infants, children and youth, adults with } \\
\text { high-prevalence conditions, and older people. }\end{array}$ \\
\hline Indigenous & $\begin{array}{l}\text { Work with First Nations, Inuit, and Métis to address their } \\
\text { mental health needs. }\end{array}$ & $\begin{array}{l}\text { Cement resiliency and recovery for Maori and Pacific. } \\
\text { Involve Maori in service planning. }\end{array}$ \\
\hline Leadership & $\begin{array}{l}\text { Mobilize "lived experience" leadership in service and } \\
\text { policy development. }\end{array}$ & $\begin{array}{l}\text { Strengthen participation and leadership of service users } \\
\text { and families at all levels. }\end{array}$ \\
\hline Knowledge & $\begin{array}{l}\text { Improve knowledge — data, research, and human resource } \\
\text { development. }\end{array}$ & $\begin{array}{l}\text { Develop targets, a workforce plan, performance indicators, } \\
\text { and best practice information sharing. }\end{array}$ \\
\hline Collaboration & $\begin{array}{l}\text { Foster collaboration at all levels, including whole-of- } \\
\text { government policy. }\end{array}$ & $\begin{array}{l}\text { Build collaboration within mental health services and } \\
\text { between mental health sector and justice sector. }\end{array}$ \\
\hline Funding & $\begin{array}{l}\text { Invest more so that mental health outcomes can be } \\
\text { improved. }\end{array}$ & Actively use our current resources more effectively. \\
\hline
\end{tabular}




\section{REFERENCES}

Mental Health Commission of Canada. (2012). Changing directions, changing lives: The mental health strategy for Canada. Calgary, AB: Author.

New Zealand Ministry of Health. (2012). Rising to the challenge: The mental health and addiction service development plan 2012-2017. Wellington, NZ: Author. 